\title{
Evaluation of Wild Foods for Responsible Human Consumption and Sustainable Use of Natural Resources
}

\author{
Jeferson Asprilla-Perea ${ }^{1}$, José M. Díaz-Puente ${ }^{2, * \mathbb{D}}$ and Susana Martín-Fernández ${ }^{3}$ (D) \\ 1 Departamento de Biología, Universidad Tecnológica del Chocó “Diego Luis Córdoba”, \\ Cra. 22 \#18b-10 Neighborhood Nicolás Medrano, Ciutadella Universitaria, \\ 270001 Quibdó, Chocó, Colombia; jeferson.asprilla@utch.edu.co \\ 2 Agricultural, Food and Biosystems Engineering School, Universidad Politécnica de Madrid, \\ Avda. Puerta de Hierro 2, 28040 Madrid, Spain \\ 3 Forestry and Natural Resources Engineering School, Universidad Politécnica de Madrid, \\ Ciudad Universitaria, 28040 Madrid, Spain; susana.martin@upm.es \\ * Correspondence: jm.diazpuente@upm.es; Tel.: +34-910-670-932
}

Received: 18 May 2020; Accepted: 16 June 2020; Published: 18 June 2020

\begin{abstract}
Traditional consumption of plants, fungi and wild animals constitutes a reality for the feeding of diverse human groups in different tropical territories of the world. In this regard, there are two views within the academic community: (1) those who defend the importance of the traditional consumption for family food security in rural areas, especially in tropical countries with emerging development; and (2) those who affirm their inconvenience as they are considered vectors of rapidly spreading diseases worldwide. A systematic literature review and an Analytic Hierarchy Process (AHP) with experts were carried out to identify the contributing criteria and dimensions in Science, Technology and Innovation (STI) that help evaluate the potential of wild foods for responsible consumption in terms of human health and nature conservation. Four dimensions were identified. The first three are: (1) importance of food for the community that consumes it $(\mathrm{w}=0.31)$; (2) nutritional value and risks for human health $(\mathrm{w}=0.28)$ and (3) sustainability of the local use of wild food model $(\mathrm{w}=0.27)$. These three obtained similar integrated relative weights, which suggests the possible balanced importance in the formulation of multidisciplinary methods for estimating the potential of wild foods. The fourth identified dimension is: (4) transformation techniques for turning wild foods into products with commercial potential, obtained an integrated relative weight of 0.14 , which, although is lower than the other three, still contributes to the potential of this type of food. The study found ten assessment criteria to evaluate the identified dimensions, constituting a starting point to estimate the potential of this type of food.
\end{abstract}

Keywords: assessment of wild food; dimensions in science; technology and innovation (STI); estimation of potential; food security; tropical forest areas

\section{Introduction}

Wild biological diversity as a source of food resources, contributes to family food security through ancestral practices of exploitation of fungi, plants and animals, especially in tropical forest areas [1]. These contributions are reflected at different levels of importance regarding their use. In many rural areas they are the main option for the consumption of animal protein, cereals, tubers, vegetables and fruits. In urban areas they constitute an alternative that complements the supply of non-wild and commercial food within the usual family basket of the territory [2-9]. Wild foods also contribute to the family economy through the generation of income from activities such as hunting, gathering, planting 
or raising plants, fungi and animals. Usually, the generation of economic income is derived from the occasional or regular sale of said products and the economic resources obtained are used for family subsistence [1].

The consumption of wild food is thus a reality for populations in different tropical territories of the world. This reality deserves a deep analysis, as there are currently different studies that attribute to zoonosis the origin of rapidly spreading diseases worldwide [10-13], and at the same time recognize the contributions of wild foods to the family food security of these territories [1]. One way of solving this dilemma is to generate empirical studies and arguments that enable responsible consumption of this type of food, understanding the processes of manipulation and ingestion of wild foods as responsible consumption that minimizes the risks to human health or biological and/or ecosystem conservation.

These studies are especially necessary in tropical areas that currently occupy some 4 billion hectares and account for about $31 \%$ of the world's land surface [14]. Some 800 million people live in these areas $[15,16]$ of whom $38 \%$ are undernourished [17]. Tropical forests are distributed in countries in Africa, Asia and Latin America and the Caribbean.

The academic community has been making efforts in Science, Technology and Innovation (STI) to address this need. Disciplinary studies define ethnobiological aspects to describe the wild species of plants, fungi or animals consumed, the frequency and forms of this consumption, as well as the social groups that consume them. This knowledge base serves to analyze the importance of these wild foods in the food security of families living in specific territories [2,8,18-22]. This type of analysis evaluates the nutritional value and risks to human health from the consumption of certain foods (bromatological studies); evaluates possible techniques to develop different products with more commercial potential [23-36]; and describes and/or enhances ancestral planting or breeding practices [37-42]. All this information allows us to understand the importance of wild foods for family food security in tropical areas. Even so, a knowledge gap continues to exist that enables identification of wild foods that can be consumed and/or manipulated without risks to human health or the conservation of natural resources. Furthermore, there is no known theoretical approach that allows the multidisciplinary estimation of the potential of wild foods from its advances in STI.

Therefore, the present study sought to contribute to the identification and definition of evaluation alternatives of those dimensions in STI that define the potential of wild foods for responsible consumption in territories associated with tropical forests. Once the dimensions are identified, a methodological process is developed to weigh and rank them according to their importance in explaining the potential of wild food. Prioritizing the dimensions according to their importance could help define a logical order in evaluating the potential of a wild food. By evaluating the most important dimension first, the non-positive results might indicate that the evaluation is not worth continuing, unless these results can be reversed through STI processes. Finally, criteria are defined to guide the practical measurement of each dimension. In order to meet these objectives, the following research questions were addressed: (1) what are the dimensions in STI that define the potential of wild foods for responsible consumption in tropical forest territories? (2) what is the relative importance of these dimensions in defining the potential of a wild food? and (3) what evaluation criteria could be defined to measure the identified dimensions?

The results generated in the present study-dimensions and evaluation criteria—will contribute to the formulation of multidisciplinary methods that allow estimating the potential of wild foods; an estimate that allows these foods to be analyzed as alternatives in planning food and nutrition security in tropical forest areas where their traditional consumption is a reality today.

\section{Methods}

The methodological process conducted in the present study was developed under three stages (see Figure 1). In the first stage, a systematic literature review was carried out, through which the main dimensions in STI that define the potential of wild foods for responsible consumption in tropical forest areas were identified. The second stage involved prioritizing these dimensions according to 
their importance in determining the potential of these foods. For the development of this stage, 15 experts were consulted. Experts were from different knowledge areas related to the use of wild foods by human populations in tropical forest areas. One of the most frequent methods applied in participatory processes in sustainable forest management [43-50] is the Analytic Hierarchy Process (AHP). This method is the most popular multiple criteria decision method used in public participation processes regarding nature resources management. In fact, according to Esmail and Geneletti [51] and Díaz-Balteiro and Romero [52] over 98 applications of this tool have been recorded in nature conservation and forest management. We applied this method to rank the dimensions in STI identified. AHP is based on pairwise comparisons between criteria and alternatives, which are compiled into square matrices whose coefficients are numerical values assigned to the preferences indicated by the participants. Finally, in the third stage the evaluation criteria were defined as a proposal to value wild foods in each of the identified dimensions.

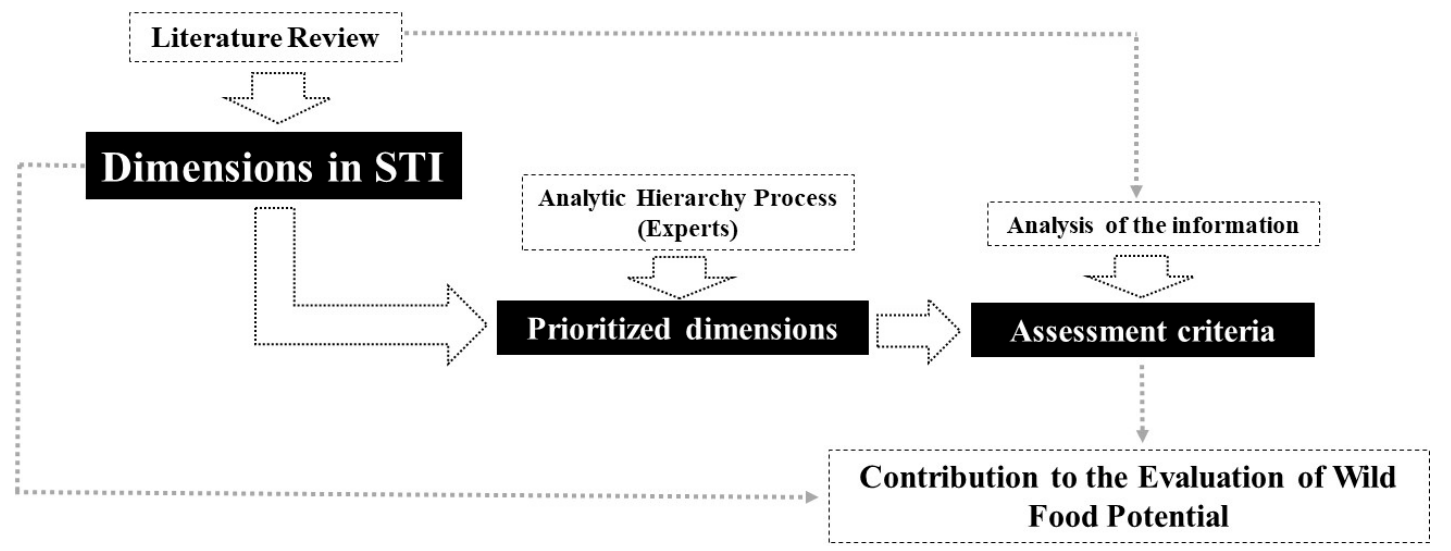

Figure 1. Methodological steps of the study.

\subsection{Identify the Dimensions (Literature Review)}

To identify the dimensions, it was necessary to previously recognize the importance of this type of food for people who use it in communities associated with tropical forests as well as the main challenges and needs in STI for responsible consumption. The recognition of the importance of wild foods and their main challenges and needs in STI was carried out through a systematic literature review, for which a methodological process of three stages was developed. That process includes: (a) identifying and obtaining documents; (b) reviewing and selecting the most relevant documents and (c) analyzing the information and structuring the results $[53,54]$.

\subsubsection{Identification and Retrieval of Documents}

A total of 182 documents were identified among books, book chapters and scientific papers. To obtain these documents, consultations were made on scientific websites: Web of ScienceTM Core Collection, BIOSIS Citation IndexSM, BIOSIS Previews ${ }^{\circledR}$, Current Contents Connect ${ }^{\circledR}$, Derwent Innovations IndexSM, Inspec ${ }^{\circledR}, M^{\prime}$ EDLINE ${ }^{\circledR}$ and SciELO Citation Index (all linked to WEB OF SCIENCE), as well as queries on Google Academic. Searches were conducted in English and Spanish using keywords in the document titles and were guided by the terms: wild foods, wild vegetables, indigenous vegetables, wild edible plants, wild meat, edible wild fruit and bushmeat. Each of the words was also searched in combination with the terms of food security and challenge. No language restrictions, years of publication, or area of knowledge were programmed.

\subsubsection{Review and Selection of Documents}

Only documents published in peer-reviewed journals or books published by renowned publishers were included. For the inclusion of a document, in addition to the above characteristics, it was verified that its content contributed to answering the research questions raised in the present study and its area 
of study corresponded to tropical forest areas. After the review and analysis process of the 182 identified documents, only 45 met the defined criteria and were included (8 books and 37 scientific articles). These 45 documents are cited in the reference section of this article and the 137 documents discarded are listed in Table A1.

\subsubsection{Analysis of Information}

Through a detailed review of the collected documents, the importance of wild foods for family food security in tropical forest areas and the main challenges and needs in STI were identified, so that this type of food could be responsibly consumed in these territories. During the analysis process for the identification of these elements, and when necessary, contributions were made to the results based on empirical experiences of the authors and/or knowledge generated during technical discussions in regular meetings.

Finally, the identification of the dimensions of technological and/or scientific knowledge that define the potential of wild foods was carried out through analyzing the main challenges and needs in STI so that this type of food could be considered as a viable alternative in food and nutritional security planning. The main arguments for the recognition of each dimension were the identification of its contribution to understanding the importance of the food for the communities that consume it or its possible contributions to the solution of the challenges and/or needs in STI.

\subsection{Prioritize the Dimensions (Analytic Hierarchy Process)}

To identify the preferences of each expert, the multicriteria decision making method Analytic Hierarchy Process (AHP) was used [55] during the last three months of 2018. According to Saaty [56]: "The purpose of the method is to enable the decision maker to structure a multi-criteria problem by building a hierarchical model". In this case the structure had two levels: objective and criteria. The objective of the model in our study was: ordering dimensions according to their capacity to define the suitability of wild food to be consumed in tropical forest areas, broken down into four criteria corresponding to the identified dimensions. The schema of this methodology is shown in Figure 2.

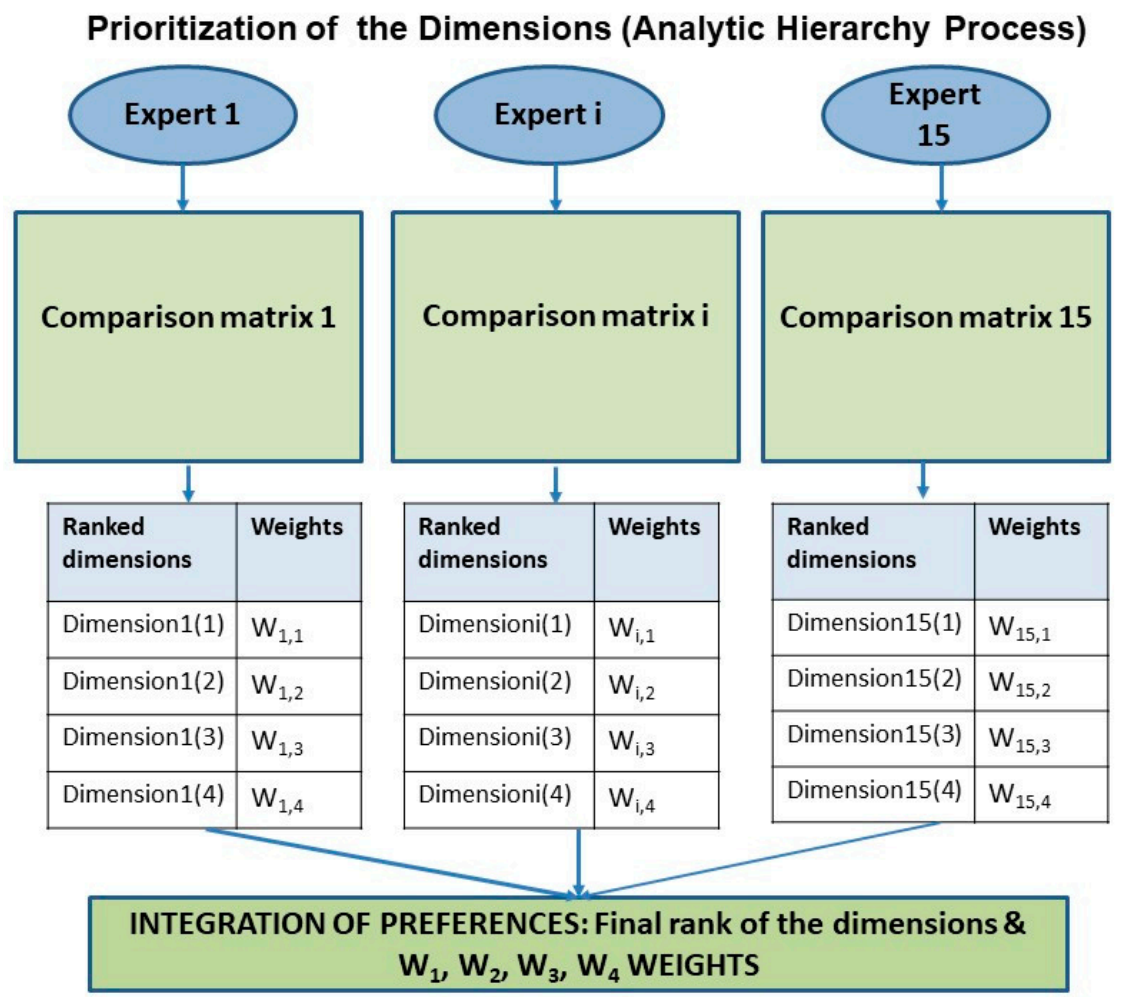

Figure 2. Structure of the dimension prioritization process. 
Pairwise comparisons were then performed between the dimensions. A pairwise comparison matrix allows subjective assessments to be converted into relatively important global scores or weights. The comparisons are done by asking the following question: How important is the Ci criterion (dimension $\mathrm{i}$ ) in relation to the $\mathrm{Cj}$ criterion (dimension $\mathrm{j}$ )?

A comparison matrix, $C 4 x 4$, is built for every participant. Every entry $C_{i, j}$ is a number representing the comparison between criteria $\mathrm{i}$ and $\mathrm{j}$, according to the scale used. A comparison matrix, $\mathrm{C}$, has three basic properties, namely positivity $\left(C_{i j}>0\right.$, for all $\left.i, j\right)$; homogeneity $\left(C_{i j}=1\right.$, if criteria $i$ and $j$ are considered equally important: specifically $C_{i i}=1$ for each $\left.i\right)$ and reciprocity $\left(C_{j i}=1 / C_{i j}\right.$ for all $\left.i, j\right)$. From this perspective, only $1 / 2 \mathrm{~m}(\mathrm{~m}-1)$ comparisons need to be made in the comparison matrix.

The AHP pairwise comparison scale was adopted from Saaty [57]:

$1=$ Both criteria equally important.

3 = Very slight importance of one criterion over the other.

$5=$ Moderate importance of one criterion over the other.

$7=$ Demonstrated importance of one criterion over the other.

$9=$ Extreme of absolute importance of one criterion over the other.

Values express intermediate preference between the two contiguous odd values.

Once all the participants' matrices were obtained, we applied the eigenvector method proposed by Saaty [57] to obtain the weights of the criteria from each matrix. As a measure of consistency of the preference (if $A$ is preferable or indifferent to $B$, and $B$ is preferable or indifferent to $C$, then $A$ is preferable or indifferent to $\mathrm{C}$ ) reflected in every matrix. We applied the Consistency Ratio $\mathrm{CR}=\mathrm{CI} / \mathrm{RI}$, to measure this transitivity, where $C I$, the Consistence Index is $C I=(\operatorname{lmax}-n) /(n-1)$ and RI, the Random Index, is $\mathrm{RI}=1.98(n-2) / n, 1 \mathrm{max}$ is the maximum eigenvalue of the matrix and $n$ the number of rows of the matrix. If CR is less than 0.1 , then the preference is consistent and the estimate is accepted.

The comparisons were done individually by 15 research experts from different tropical countries with training profiles and/or research experience in different areas of knowledge. These areas include: (1) ethnobiology, (2) food and nutritional security, (3) agronomy and/or zootechnics, (4) biology and/or ecology, (5) agricultural and/or natural resources economics and (6) agroindustry. The quality requirements defined for the selection of the experts were: Doctor's degree $(\mathrm{PhD})$ with scientific publications in high-quality indexed journals and having participated in research projects in their area of knowledge.

The results obtained by each expert were averaged to obtain the final relative weight of each dimension by the area of knowledge (see Figure 2). For each area of knowledge, the dimensions were ordered by their importance and a hierarchy of importance was drawn that defined the potential of wild foods for responsible consumption in territories associated with tropical forests.

In addition, three analyses of variance were carried out to see the relationship among the factors "Area of knowledge" and "Dimension", and the quantitative variable "Weight" obtained with the AHP method. These three analyses were: (1) analysis of the influence of the "Area of knowledge" on the average behavior of the variable "Weight" of the expert; (2) analysis of the influence of the "Dimension" on the average behavior of the variable "Weight" of the expert and (3) if the factor "Dimension" influenced the integrated value of the "Weights by area of knowledge".

\subsection{Define the Criteria}

Once the dimensions were obtained and prioritized, a set of evaluation criteria was defined based on the needs identified in STI during the literature review. The evaluation criteria were obtained from a rigorous analysis process on the STI needs related to each of the identified dimensions. From this perspective, a matrix was built in which each evaluation criterion responds to a mechanism to solve a need in STI. The evaluation criteria constitute the minimum conditions a wild food must meet for responsible consumption or for being considered as a viable alternative in the planning of food and nutritional security for tropical forest territories. Based on the results, a set of dimensions and their 
respective evaluation criteria is proposed to check the minimum conditions of wild food with respect to its advances in STI.

\section{Results}

\subsection{Key Challenges in STI of Wild Foods}

Two main challenges in STI were identified in the literature review. They are the challenges for wild food to be consumed in a responsible way or considered as a viable alternative in the planning of food and nutrition security in tropical forest areas. They are related to (1) the negative effects on biodiversity conservation as a result of unplanned extractive harvesting practices and (2) the possible risks to human health due to the lack of assessment of their nutritional and health quality.

With regard to the first challenge, some studies conducted in different areas of tropical forest in Africa and Latin America show concerns about the frequent and extractive use of wild plants, fungi and animals. The most negative effects in the medium and long term are the reduction of populations of vulnerable species, local extinction and habitat fragmentation, with consequences on the functioning of ecosystems and people's lives [1,9,58-62].

Concerning the second challenge, food products whose nutrition has not been studied, can generate food imbalances for individuals who consume them instead of providing nutrients. This would be counterproductive for food security [2,5,63,64]. In addition, more than 35 new infectious diseases have emerged in humans [53] in recent decades, many of which are attributed to the handling and consumption of plants, fungi or jungle animals [2,5,11-13,63-67]. Nevertheless, the consumption of plants, fungi and wild animals in tropical forest areas as food is not commonly related to government food security policies. On the contrary, this consumption is related to the ancestral traditions and socio-cultural customs of local communities.

On a higher-detailed scale, these challenges could be expressed through the following needs and dimensions in STI identified in the literature review.

\subsection{Needs and Dimensions in STI That Define the Potential of Wild Foods}

Ten needs in STI were identified in the literature review. They were analyzed and conceptualized in four technological and/or scientific knowledge dimensions. These dimensions in STI constitute the structural axes for estimating the potential of wild foods for responsible consumption as an alternative resource in the planning of interventions in favor of food and nutrition security for tropical forest territories. These dimensions are: (a) importance of food for the community that consumes it; (b) sustainability of the local model of wild food use; (c) nutritional value and risks to human health and (d) processing techniques into products with commercial potential. By its nature, the understanding of these dimensions must be addressed from a multidisciplinary approach since knowledge is required from different disciplines for the study such as sociology, anthropology, biology, ecology, economics, agronomy, zootechnics, veterinary sciences and laws, among others. Each dimension and its respective needs in STI are detailed below.

\subsubsection{Importance of Food for the Community That Consumes It}

This dimension defines the importance of wild foods based on traditional uses and other aspects that shape the use of a food in a specific community. The food whose pattern of use (obtained through scientific research) demonstrates the importance of this edible food's usage for the territory will have greater potential. Below are the needs for advances in STI related to the dimension: (1) recognition and documentation of the traditional use of wild species in the feeding of communities living in tropical forest territories to include lists of species used as food and studies with different types of use where food is included, etc.; (2) recognition of the pattern of use of wildlife in the feeding of communities in tropical forest areas, with special emphasis on the species/culture/territory relationship and parts of the plant, fungus or animal used, ways of use, frequency of use, economic assessment of 
the contribution of these products to food and nutritional security, etc., and (3) identification of drivers for the consumption of wild foods including preferences between wild and non-wild foods, limitations to obtaining other alternatives, effects of culture on the consumption of wild foods, etc.

\subsubsection{Sustainability of the Local Model of Wild Food Use}

This dimension is based on the sustainability of the source from which wild food could be obtained for family consumption and contribution to food and nutritional security in the territory. The wild food will have greater potential if it has at least a sustainable harvesting mechanism tested in the territory. The needs for advances in STI related to the dimension are: (1) recognition of supply sources of the wild food in the territory whether extractive and/or non-extractive use; (2) generation of technological and/or scientific knowledge on mechanisms for the sustainable use of wild food and (3) cost/benefit analysis of such mechanisms.

\subsubsection{Nutritional Value and Risks to Human Health}

This dimension is based on technological and/or scientific knowledge about the nutritional value of wild food products and the assessment of possible risks to human health due to their intake. The wild food with known nutritional value whose result is similar or better than commercial non-wild foods belonging to the same group (fruit vs. fruit, meat vs. meat, vegetables vs. vegetables, etc.) will have greater potential. Food with studies showing that its consumption does not create risks to human health will also have greater potential. Below are the needs for advances in STI related to this dimension: (1) identification of the nutritional value of wild food products being consumed by human populations in the territory studied; (2) identification of the biological assimilation of these wild food products and (3) assessment of food quality with regard to risks to human health due to its consumption.

\subsubsection{Processing Techniques into Products with Commercial Potential}

This dimension values the technological and/or scientific knowledge advances about the transformation of wild foods into products with potential economic importance for human communities. Food with advances in technological developments that allow transformation into products with commercial potential will have greater overall potential. There is one need for advances in STI related to this dimension and that is: the generation of scientific knowledge, experimental developments and/or technological developments for the transformation of raw materials into products with commercial potential.

\subsection{Sorting of the Dimensions According to Experts' Preferences}

Once the dimensions were identified, each expert using the AHP method arranged them in order. The results of this consultation with the fifteen experts and the application of the AHP method can be found in Table 1.

As a result of the application of the AHP method by each expert, the importance of each dimension for each expert was obtained. This importance was expressed by the weights shown in Table 1. These were the weights obtained for each expert who was using the AHP process for each dimension. In Table 1, the experts were grouped according to their knowledge area to make it easier to compare results.

Table 1 also shows that the consistency of preference for all experts was acceptable since no CR value had exceeded the limit value of 0.1 [57]. 
Table 1. Analytic Hierarchy Process (AHP) weights for each expert Ei of each knowledge area, for each dimension and Consistency Ratio (CR).

\begin{tabular}{|c|c|c|c|c|c|c|c|c|c|c|c|c|c|c|c|}
\hline \multirow{2}{*}{$\begin{array}{c}\text { Dimensions/Knowledge } \\
\text { Area }\end{array}$} & \multicolumn{3}{|c|}{$\begin{array}{l}\text { Agronomy and/or } \\
\text { Zootechnics }\end{array}$} & \multicolumn{2}{|c|}{ Agroindustry } & \multicolumn{3}{|c|}{ Biology and/or Ecology } & \multicolumn{2}{|c|}{$\begin{array}{l}\text { Natural Resources } \\
\text { Economics }\end{array}$} & \multicolumn{2}{|c|}{ Ethnobiology } & \multicolumn{3}{|c|}{$\begin{array}{c}\text { Food and } \\
\text { Nutritional Security }\end{array}$} \\
\hline & E1 & E2 & E3 & E4 & E5 & E6 & E7 & E8 & E9 & E10 & E11 & E12 & E13 & E14 & E15 \\
\hline $\begin{array}{l}\text { Importance of food for the } \\
\text { community that consumes it }\end{array}$ & 0.15 & 0.43 & 0.25 & 0.59 & 0.61 & 0.43 & 0.28 & 0.04 & 0.31 & 0.22 & 0.14 & 0.23 & 0.20 & 0.09 & 0.33 \\
\hline $\begin{array}{l}\text { Sustainability of the local } \\
\text { model of wild food use }\end{array}$ & 0.64 & 0.04 & 0.25 & 0.12 & 0.05 & 0.09 & 0.57 & 0.10 & 0.56 & 0.15 & 0.14 & 0.29 & 0.59 & 0.25 & 0.49 \\
\hline $\begin{array}{l}\text { Nutritional value and risks } \\
\text { to human health }\end{array}$ & 0.15 & 0.42 & 0.25 & 0.20 & 0.09 & 0.05 & 0.10 & 0.60 & 0.08 & 0.47 & 0.48 & 0.37 & 0.12 & 0.63 & 0.13 \\
\hline $\begin{array}{l}\text { Processing techniques into } \\
\text { products with } \\
\text { commercial potential. }\end{array}$ & 0.05 & 0.11 & 0.25 & 0.09 & 0.25 & 0.43 & 0.04 & 0.25 & 0.05 & 0.15 & 0.23 & 0.10 & 0.09 & 0.04 & 0.05 \\
\hline Consistency Rate (CR) & 0.04 & 0.09 & 0 & 0.07 & 0.07 & 0.02 & 0.08 & 0.03 & 0.04 & 0 & 0 & 0 & 0.04 & 0 & 0.08 \\
\hline
\end{tabular}


Once the results from the AHP method were obtained, they were analyzed using an ANOVA if the knowledge area to which each expert belonged influenced the AHP results. The $p$-value of this test was 1 , so we could not reject that the knowledge area did not influence the average behavior of the variable AHP-weight. The residuals met the requirements of normality, ( $p$-value of the Kolmogorov-Smirnov test $=0.084217)$, homoscedasticity (Levene's test $p$-value $=0.4972$ ), independence (autocorrelation coefficient for lag $=1$ was -0.23514 , which did not belong to the $95 \%$ Confidence Interval $(-0.250031$; $0.253031)$ ), and the residuals average was 0 .

These findings allowed us to analyze the AHP weights as a whole and not by the knowledge area. We ranked for every expert the dimensions from the most preferred to the least according to their AHP weight value and also integrated the AHP weights of the experts calculating the geometric mean. Table 2 shows the global results of this ranking.

Table 2. Global preference order of the dimensions according to the experts' individual rankings.

\begin{tabular}{|c|c|c|c|c|c|c|c|c|}
\hline Dimension & $\begin{array}{l}\text { First } \\
\text { Place }\end{array}$ & $\begin{array}{l}\text { Second } \\
\text { Place }\end{array}$ & $\begin{array}{l}\text { Third } \\
\text { Place }\end{array}$ & $\begin{array}{l}\text { Fourth } \\
\text { Place }\end{array}$ & Total & $\begin{array}{c}\text { Weight } \\
\text { Integrated Value }\end{array}$ & $\begin{array}{l}\text { Standard } \\
\text { Deviation }\end{array}$ & $\begin{array}{c}\text { Final } \\
\text { Ranking }\end{array}$ \\
\hline $\begin{array}{l}\text { Importance of food for the } \\
\text { community that consumes it }\end{array}$ & 5 & 6 & 3 & 1 & 15 & 0.31 & 0.17 & 1 \\
\hline $\begin{array}{l}\text { Sustainability of the local } \\
\text { model of wild food use }\end{array}$ & 6 & 2 & 4 & 3 & 15 & 0.27 & 0.22 & 3 \\
\hline $\begin{array}{l}\text { Processing techniques into } \\
\text { products with } \\
\text { commercial potential }\end{array}$ & 1 & 4 & 2 & 8 & 15 & 0.14 & 0.11 & 4 \\
\hline
\end{tabular}

The first columns of Table 2 show how many times each dimension has been chosen from first place to the last one for the 15 experts together. These data have been obtained from Table 1 by ordering the dimensions from the most preferred to the last for each expert and then counting how many times each dimension is ranked in first, second, third or fourth place. The dimensions appear in the table in order of preference. The result from the consultation with experts strictly analyzed by the relative weight values suggest the dimension "Importance of food for the community that consumes it" as the most important in defining the potential of wild foods for responsible consumption. A total of 11 experts out of 15 considered it as the first or second most important dimension. The following dimensions in order of importance would be: "Nutritional value and risks to human health" and "Sustainability of the local model of wild food use" with practically equal integrated weights: 0.28 and 0.27 respectively. The number of experts who consider them as the most important dimension is the same, and they are the dimensions in which the standard deviation has been highest. Finally, the dimension considered to be in the 4 th position, by more than 50\% of the experts, was "Processing techniques into products with commercial potential".

\subsection{Criteria for Assessing the Potential of Wild Foods}

Based on the literature review, ten assessment criteria are proposed according to the needs in STI identified in each dimension. These criteria include the minimum conditions that a wild food must meet to be responsibly considered for its consumption in territories associated with tropical forests. Figure 3 shows the assessment criteria for each of the dimensions. 


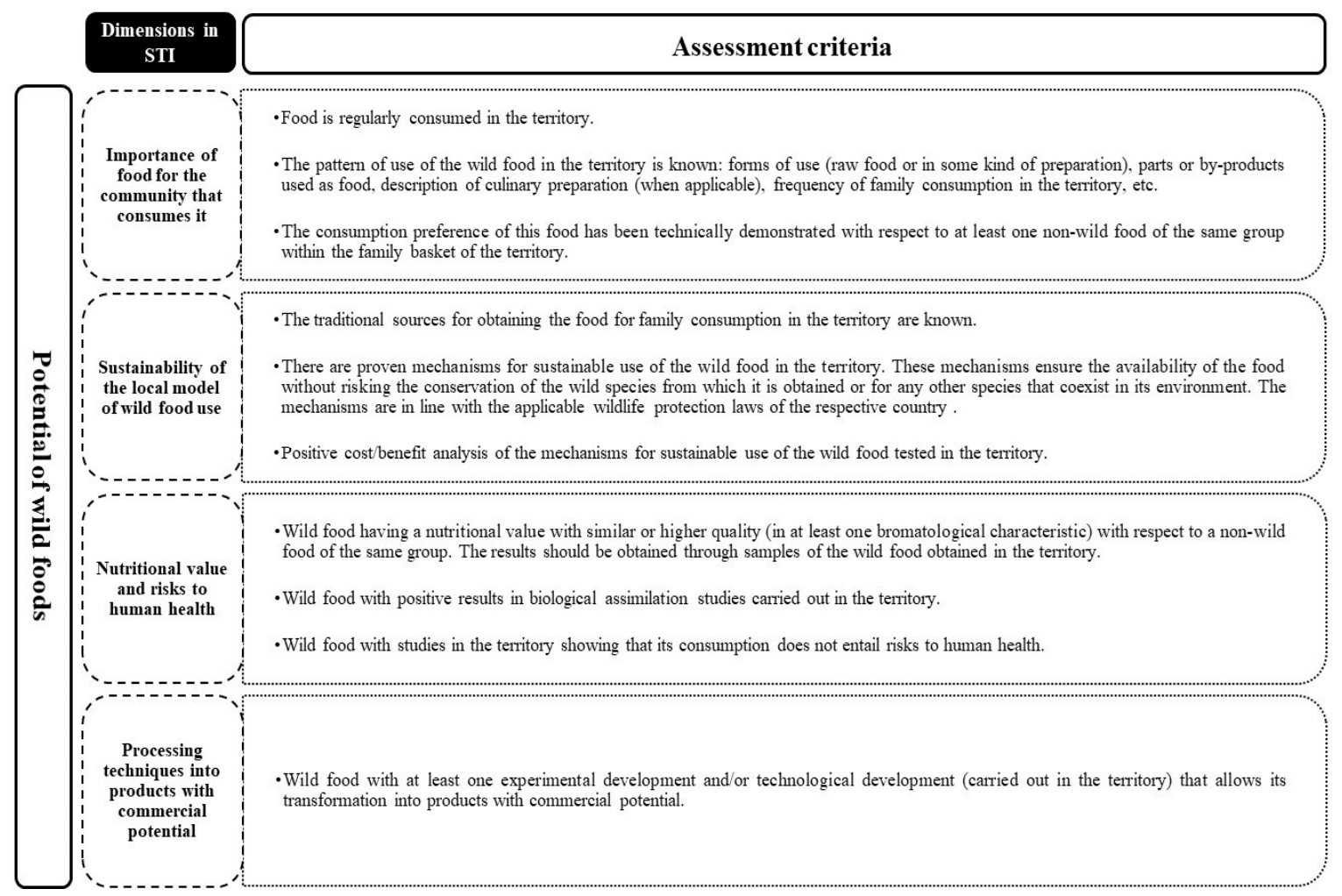

Figure 3. Evaluation criteria for each of the Science, Technology and Innovation (STI) dimensions that define the potential of wild foods.

\section{Discussion and Conclusions}

The dimensions identified in this study were related to the approach of Arenas and Scarpa [68] where it is stated that the recognition of the potential for human consumption of wild fruits depends on three aspects: cultural acceptance, the abundance of the species in their natural environment and fruit quality. The present research built upon this and proposed four dimensions in STI that define the potential of wild foods as an alternative resource in the planning of food and nutritional security for tropical forest territories. These dimensions are: (a) importance of the food for the community that consumes it; (b) sustainability of the utilization model, (c) nutritional value and risks to human health and $(\mathrm{d})$ processing techniques into products with commercial potential.

The integration of the opinion of the experts has allowed ordering the dimensions by their importance. The consistency of the results makes this ordering applicable in the decision-making process. The results of AHP indicate the unanimity when considering the dimension "Importance of food for the community that consumes it" the most important one. A diet should not be imposed if there is no local tradition in its consumption. It is assumed that initiatives concerning food and nutritional security that include traditional food in the territory could be more relevant and sustainable.

The AHP results also show that the nutritional quality of food consumed by the population should be explored and considered first, as well as the management of sustainable use mechanisms, before considering the processing of wild food and its exploitation for sale in local markets or other places. On the other hand, the differences between the integrated weights of the first three dimensions (a, b and c) vary between 8 and 10\%, lower than the variability of the weights of these dimensions (see Table 2). This indicates, for practical purposes, the need to consider the dimensions with equal demand when deciding whether a food should be incorporated into the diet of a population or not.

Knowing the "Importance of food for the community that consumes it", (a) how often it is consumed and what people in the community consume it, is decisive in managing the foods, since cultural preferences and traditional practices tend to maintain them and their modification is 
difficult [69]. Failure to apply sustainable wild food management (b) can lead to over-exploitation of these species. In the case of forest species there is frequently multiple use of these items as food, firewood, construction or fencing [69]. The dimension of "Nutritional value and risks to human health" (c) will allow measuring whether the wild food consumed by a community meets the requirements of an adequate diet for the population, as demonstrated by the work of Fungo et al. [70] in Nigeria, Gabon and Congo, where, due to wild berries, they are able to get an adequate diet. Knowing the nutritional value of food determines its safety for the health of the community. The lack of studies on the risks consumption entails for human health can cause serious stomach problems, pains in the chest or even the death in these tropical areas [71]; or complex problems such as the COVID-19 pandemic [11-13], which is attributed by some experts to the unplanned management and consumption of wildlife.

The results of the fourth dimension on processing techniques (d) also show their contribution to estimating the potential of wild foods, but the other three dimensions should be addressed as a priority and are considered by experts to be more important.

The ten criteria defined for the evaluation of the four dimensions form the basis to create mechanism that allow the formulation of multidisciplinary methods (qualitative and/or quantitative) for estimating the potential of wild foods for responsible consumption or as an feasible alternative in planning food and nutrition security for territories associated with tropical forests.

The dimensions and criteria presented are not intended to be suggested as absolute variables for evaluating the potential of wild foods for responsible consumption in tropical forest areas. On the contrary, this study seeks to contribute to discussions on methods for multidisciplinary estimation of the potential of this type of food that, although not officially included in the planning of food security policies, does constitute a reality for the food of various human groups in different tropical territories on this planet.

Author Contributions: Conceptualization, J.A.-P. and J.M.D.-P.; methodology, J.A.-P., J.M.D.-P. and S.M.-F.; software, S.M.-F.; validation, J.A.-P., J.M.D.-P. and S.M.-F.; formal analysis, J.A.-P., J.M.D.-P. and S.M.-F.; investigation, J.A.-P., J.M.D.-P. and S.M.-F.; resources, J.A.-P. and J.M.D.; data curation, S.M.; writing-original draft preparation, J.A.-P., J.M.D. and S.M.; writing—review and editing, J.A.-P., J.M.D. and S.M.; visualization, J.A.-P. and S.M.-F.; supervision, J.A.-P., J.M.D.-P. and S.M.-F.; project administration, J.A.-P. and J.M.D.-P. All authors have read and agreed to the published version of the manuscript.

Funding: This research received no external funding.

Acknowledgments: The authors thank Ramón Rosales, Clara María Mejía Doria, Francisco Javier Castellanos Galeano, Israel Ríos Castillo, Hamleth Valois Cuesta, Rubén Cornelio Montes Pérez, Hugo Fernando López Arévalo, Oscar Vergara Garay, Oscar Gustavo Retana Guiascón, Julio Ricardo Sanabria Botero, William Narváez-Solarte, Alex Mauricio Jiménez Ortega, Mélida Martínez Guardia, Ana Afonso Gallegos and Harley Quinto Mosquera for their valuable technical contribution in the application of AHP. They also wish to express their gratitude to the Technological University of Chocó and the Technical University of Madrid for their institutional support.

Conflicts of Interest: The authors declare no conflict of interest. 


\section{Appendix A}

Table A1. Documents discarded in the literature review and not listed in the reference section.

\begin{tabular}{|c|c|c|c|c|c|}
\hline Geographical Area & Journal Name & Document Type & Document Title & Language & Year of Publication \\
\hline Africa & Energy Policy & Paper & $\begin{array}{c}\text { Biofuels and food security: Micro-evidence from } \\
\text { Ethiopia }\end{array}$ & English & 2013 \\
\hline Africa & Energy Policy & Paper & $\begin{array}{l}\text { Potential impacts of biofuel development on food } \\
\text { security in Botswana: A contribution to energy policy }\end{array}$ & English & 2012 \\
\hline Africa & African Affairs & Paper & Biofuels, food security, and Africa & English & 2010 \\
\hline Africa & $\begin{array}{c}\text { International Food and } \\
\text { Agribusiness Management Review }\end{array}$ & Paper & $\begin{array}{l}\text { The Impact of biofuel production on food security: } \\
\text { A briefing paper with a particular emphasis on } \\
\text { maize-to-ethanol production }\end{array}$ & English & 2008 \\
\hline Africa & $\begin{array}{l}\text { Economics-The Open Access } \\
\text { Open-Assessment E-Journal }\end{array}$ & Paper & $\begin{array}{l}\text { South African food security and climate change: } \\
\text { Agriculture futures }\end{array}$ & English & 2013 \\
\hline Africa & Review of Development Economics & Paper & $\begin{array}{c}\text { Climate change, agriculture and food security } \\
\text { in Tanzania }\end{array}$ & English & 2012 \\
\hline Africa & Climate and Development & Paper & $\begin{array}{c}\text { Climate variability, yield instability and global } \\
\text { recession: The multi-stressor to food security } \\
\text { in Botswana }\end{array}$ & English & 2012 \\
\hline Africa & Climatic Change & Paper & $\begin{array}{c}\text { East African food security as influenced by future } \\
\text { climate change and land use change at local to } \\
\text { regional scales }\end{array}$ & English & 2012 \\
\hline Africa & $\begin{array}{c}\text { International Journal of Pest } \\
\text { Management }\end{array}$ & Paper & $\begin{array}{l}\text { Food security, politics and perceptions of wildlife } \\
\text { damage in Western Ethiopia }\end{array}$ & English & 2012 \\
\hline Africa & $\begin{array}{l}\text { International Journal of Climate } \\
\text { Change Strategies and } \\
\text { Management }\end{array}$ & Paper & $\begin{array}{c}\text { Gendered response and risk-coping capacity to } \\
\text { climate variability for sustained food security in } \\
\text { Northern Cameroon }\end{array}$ & English & 2012 \\
\hline Africa & $\begin{array}{l}\text { Environment Development and } \\
\text { Sustainability }\end{array}$ & Review paper & $\begin{array}{l}\text { Climate change and variability in Sub-Saharan Africa: } \\
\text { A review of current and future trends and impacts on } \\
\text { agriculture and food security }\end{array}$ & English & 2011 \\
\hline Africa & $\begin{array}{c}\text { American Journal of Agricultural } \\
\text { Economics }\end{array}$ & Paper & $\begin{array}{l}\text { Does adaptation to climate change provide food } \\
\text { security? A micro-perspective from Ethiopia }\end{array}$ & English & 2011 \\
\hline
\end{tabular}


Table A1. Cont.

\begin{tabular}{|c|c|c|c|c|c|}
\hline Geographical Area & Journal Name & Document Type & Document Title & Language & Year of Publication \\
\hline Africa & $\begin{array}{l}\text { Mitigation and Adaptation } \\
\text { Strategies for Global Change }\end{array}$ & Paper & $\begin{array}{c}\text { Food security and climate change in drought-sensitive } \\
\text { savanna zones of Ghana }\end{array}$ & English & 2011 \\
\hline Africa & Area & Paper & $\begin{array}{c}\text { Farming flexibility and food security under climatic } \\
\text { uncertainty: Manang, Nepal Himalaya }\end{array}$ & English & 2010 \\
\hline Africa & Sustainability Science & Paper & $\begin{array}{l}\text { Food security and seasonal climate information: } \\
\text { Kenyan challenges }\end{array}$ & English & 2010 \\
\hline Africa & Journal of Human Ecology & Paper & $\begin{array}{l}\text { Climate variability, environment change and food } \\
\text { security nexus in Nigeria }\end{array}$ & English & 2009 \\
\hline Africa & $\begin{array}{l}\text { Environmental Science } \\
\text { and Technology }\end{array}$ & Paper & $\begin{array}{c}\text { Markets, climate change, and food security in } \\
\text { West Africa }\end{array}$ & English & 2009 \\
\hline Africa & Erdkunde & Paper & $\begin{array}{l}\text { Climate change and food security in tropical West } \\
\text { Africa-A dynamic-statistical modeling approach }\end{array}$ & English & 2008 \\
\hline Africa & $\begin{array}{l}\text { Journal of Energy in } \\
\text { Southern Africa }\end{array}$ & Paper & $\begin{array}{l}\text { The impacts of climate change on food security and } \\
\text { health in Southern Africa }\end{array}$ & English & 2008 \\
\hline Africa & $\begin{array}{l}\text { Proceedings of the National } \\
\text { Academy of Sciences of the United } \\
\text { States of America }\end{array}$ & Paper & $\begin{array}{l}\text { Warming of the Indian Ocean threatens eastern and } \\
\text { southern African food security but could be mitigated } \\
\text { by agricultural development }\end{array}$ & English & 2008 \\
\hline Africa & Climatic Change & Paper & $\begin{array}{l}\text { The economic and food security implications of } \\
\text { climate change in Mali }\end{array}$ & English & 2005 \\
\hline Africa & $\begin{array}{l}\text { Philosophical Transactions of the } \\
\text { Royal Society B-biological Sciences }\end{array}$ & Paper & $\begin{array}{l}\text { Weather patterns, food security and humanitarian } \\
\text { response in sub-Saharan Africa }\end{array}$ & English & 2005 \\
\hline Africa & Agricultural Water Management & Paper & $\begin{array}{l}\text { Adaptation to climate change to enhance food security } \\
\text { and preserve environmental quality: example for } \\
\text { southern Sri Lanka }\end{array}$ & English & 2004 \\
\hline Africa & Food and Nutrition Bulletin & Paper & $\begin{array}{l}\text { Food security indicators after humanitarian } \\
\text { interventions including food aid in Zimbabwe }\end{array}$ & English & 2010 \\
\hline Africa & Agrekon & Paper & $\begin{array}{c}\text { The status of household food security targets in } \\
\text { South Africa }\end{array}$ & English & 2009 \\
\hline
\end{tabular}


Table A1. Cont.

\begin{tabular}{|c|c|c|c|c|c|}
\hline Geographical Area & Journal Name & Document Type & Document Title & Language & Year of Publication \\
\hline Africa & Disasters & Paper & $\begin{array}{l}\text { Measuring populations' vulnerabilities for famine and } \\
\text { food security interventions: the case of Ethiopia's } \\
\text { Chronic Vulnerability Index }\end{array}$ & English & 2008 \\
\hline Africa & Disasters & Paper & $\begin{array}{c}\text { The underutilization of street markets as a source of } \\
\text { food security indicators in Famine Early Warning } \\
\text { Systems: a case study of Ethiopia }\end{array}$ & English & 2008 \\
\hline Africa & Food Culture and Society & Paper & $\begin{array}{l}\text { Toward improved understanding of food security a } \\
\text { methodological examination based in rural } \\
\text { South Africa }\end{array}$ & English & 2013 \\
\hline Africa & $\begin{array}{l}\text { Systems Research and } \\
\text { Behavioral Science }\end{array}$ & Paper & $\begin{array}{l}\text { Designing sustainable food security policies in } \\
\text { sub-Saharan African countries: How social dynamics } \\
\text { over-ride utility evaluations for good and bad }\end{array}$ & English & 2012 \\
\hline North America & $\begin{array}{l}\text { Economics-The Open Access } \\
\text { Open-Assessment E-Journal }\end{array}$ & Paper & $\begin{array}{l}\text { US food security and climate change: } \\
\text { Agricultural futures }\end{array}$ & English & 2013 \\
\hline North America & Ecohealth & Paper & $\begin{array}{l}\text { Adapting to the impacts of climate change on food } \\
\text { security among Inuit in the Western Canadian Arctic }\end{array}$ & English & 2010 \\
\hline North America & $\begin{array}{l}\text { International Journal of } \\
\text { Circumpolar Health }\end{array}$ & Paper & $\begin{array}{c}\text { Local observations of climate change and impacts on } \\
\text { traditional food security in two northern } \\
\text { Aboriginal communities }\end{array}$ & English & 2006 \\
\hline North America & Ambio & Paper & $\begin{array}{l}\text { A call for urgent monitoring of food and water } \\
\text { security based on relevant indicators for the Arctic }\end{array}$ & English & 2013 \\
\hline North America & Journal of Nutrition & Paper & $\begin{array}{l}\text { Food security of older adults requesting older } \\
\text { Americans act nutrition program in Georgia can be } \\
\text { validly measured using a short form of the U.S. } \\
\text { household food security survey module }\end{array}$ & English & 2011 \\
\hline North America & Public Health Nutrition & Paper & $\begin{array}{c}\text { Does interview mode matter for food security } \\
\text { measurement? Telephone versus in-person interviews } \\
\text { in the current population survey food } \\
\text { security supplement }\end{array}$ & English & 2007 \\
\hline
\end{tabular}


Table A1. Cont.

\begin{tabular}{|c|c|c|c|c|c|}
\hline Geographical Area & Journal Name & Document Type & Document Title & Language & Year of Publication \\
\hline North America & Public Health Nutrition & Paper & $\begin{array}{c}\text { The assessment of food security in homeless } \\
\text { individuals: a comparison of the Food Security } \\
\text { Survey Module and the Household Food Insecurity } \\
\text { Access Scale }\end{array}$ & English & 2011 \\
\hline North America & Journal of Nutrition & Paper & $\begin{array}{l}\text { Recent advances provide improved tools for } \\
\text { measuring children's food security }\end{array}$ & English & 2007 \\
\hline Arctic & $\begin{array}{l}\text { International Journal of } \\
\text { Circumpolar Health }\end{array}$ & Paper & $\begin{array}{l}\text { Indicators of food and water security in an Arctic } \\
\text { health context-results from an international } \\
\text { workshop discussion }\end{array}$ & English & 2013 \\
\hline Asia & $\begin{array}{l}\text { Renewable and Sustainable } \\
\text { Energy Reviews }\end{array}$ & Review paper & Biofuel and food security in China and Japan & English & 2013 \\
\hline Asia & $\begin{array}{l}\text { Mountain Research and } \\
\text { Development }\end{array}$ & Paper & $\begin{array}{l}\text { Solar greenhouse technology for food security: A case } \\
\text { study from Humla District, NW Nepal }\end{array}$ & English & 2012 \\
\hline Asia & Renewable Energy & Paper & $\begin{array}{l}\text { Will the development of bioenergy in China create a } \\
\text { food security problem? Modeling with fuel ethanol as } \\
\text { an example }\end{array}$ & English & 2012 \\
\hline Asia & Journal of Environmental Quality & Paper & $\begin{array}{c}\text { Biofuel development, food security and the use of } \\
\text { marginal land in China }\end{array}$ & English & 2011 \\
\hline Asia & $\begin{array}{c}\text { Energy for } \\
\text { Sustainable Development }\end{array}$ & Paper & Bioenergy and food security: Indian context & English & 2009 \\
\hline Asia & Philippine Agricultural Scientist & Paper & $\begin{array}{l}\text { Sugar as a biofuel: Implications for Philippine } \\
\text { agriculture and food security }\end{array}$ & English & 2008 \\
\hline Asia & $\begin{array}{c}\text { Agronomy for } \\
\text { Sustainable Development }\end{array}$ & Paper & Climate change impact on China food security in 2050 & English & 2013 \\
\hline Asia & $\begin{array}{l}\text { Journal of Food Agriculture and } \\
\text { Environment }\end{array}$ & Paper & $\begin{array}{c}\text { Climate change, agriculture and food security issues: } \\
\text { Malaysian perspective }\end{array}$ & English & 2013 \\
\hline Asia & Sustainability & Paper & $\begin{array}{l}\text { Impact of climate and land use changes on water and } \\
\text { food security in Jordan: Implications for transcending } \\
\text { "The tragedy of the commons" }\end{array}$ & English & 2013 \\
\hline
\end{tabular}


Table A1. Cont.

\begin{tabular}{|c|c|c|c|c|c|}
\hline Geographical Area & Journal Name & Document Type & Document Title & Language & Year of Publication \\
\hline Asia & $\begin{array}{l}\text { Environmental Modeling } \\
\text { and Assessment }\end{array}$ & Paper & $\begin{array}{l}\text { Modeling of ecological footprint and climate change } \\
\text { impacts on food security of the hill tracts of } \\
\text { Chittagong in Bangladesh }\end{array}$ & English & 2013 \\
\hline Asia & Chinese Geographical Science & Paper & $\begin{array}{l}\text { Soil degradation and food security coupled with } \\
\text { global climate change in northeastern China }\end{array}$ & English & 2013 \\
\hline Asia & Ambio & Review paper & $\begin{array}{l}\text { Climate change and population growth in Timor } \\
\text { Leste: Implications for food security }\end{array}$ & English & 2012 \\
\hline Asia & Food Security & Paper & $\begin{array}{l}\text { Adaptation to climate change for food security in the } \\
\text { lower Mekong Basin }\end{array}$ & English & 2011 \\
\hline Asia & $\begin{array}{l}\text { Journal of Developments in } \\
\text { Sustainable Agriculture }\end{array}$ & Paper & $\begin{array}{c}\text { Enhancing food security in the context of climate } \\
\text { change and the role of higher education institutions in } \\
\text { the Philippines }\end{array}$ & English & 2010 \\
\hline Asia & $\begin{array}{l}\text { Asia Pacific Journal of } \\
\text { Clinical Nutrition }\end{array}$ & Review paper & Climate change and food security in East Asia & English & 2009 \\
\hline Asia & Food Security & Paper & $\begin{array}{l}\text { Climate change, flooding and food security in } \\
\text { south Asia }\end{array}$ & English & 2009 \\
\hline Asia & Climatic Change & Paper & $\begin{array}{c}\text { Climate change, land use change, and China's food } \\
\text { security in the twenty-first century: } \\
\text { An integrated perspective }\end{array}$ & English & 2009 \\
\hline Asia & $\begin{array}{l}\text { Asia Pacific Journal of } \\
\text { Clinical Nutrition }\end{array}$ & Review paper & $\begin{array}{l}\text { Food security in the Asia-Pacific: Climate change, } \\
\text { phosphorus, ozone and other } \\
\text { environmental challenges }\end{array}$ & English & 2009 \\
\hline Asia & Environmental Management & Paper & $\begin{array}{l}\text { Food security in the face of climate change, } \\
\text { population growth, and resource constraints: } \\
\text { Implications for Bangladesh }\end{array}$ & English & 2004 \\
\hline Asia & $\begin{array}{l}\text { Bulletin of Indonesian } \\
\text { Economic Studies }\end{array}$ & Paper & $\begin{array}{l}\text { Using climate models to improve Indonesian } \\
\text { food security }\end{array}$ & English & 2004 \\
\hline Asia & The Journal of Nutrition & Journal Article & $\begin{array}{l}\text { Development and validation of an Arab family food } \\
\text { security scale }\end{array}$ & English & 2014 \\
\hline
\end{tabular}


Table A1. Cont.

\begin{tabular}{|c|c|c|c|c|c|}
\hline Geographical Area & Journal Name & Document Type & Document Title & Language & Year of Publication \\
\hline Asia & Advanced Materials Research & Paper & $\begin{array}{l}\text { Established the evaluation index system of food } \\
\text { security in state farms of Heilongjiang province }\end{array}$ & English & 2011 \\
\hline Asia & Public Health Nutrition & Paper & An empirical study of Taiwan's food security index & English & 2010 \\
\hline Asia & $\begin{array}{c}\text { Journal of Preventive Medicine and } \\
\text { Public Health = Yebang Uihakhoe } \\
\text { Chi }\end{array}$ & Review paper & The concept and measurement of food security & Korean & 2008 \\
\hline Asia & $\begin{array}{l}\text { Asia Pacific Journal of } \\
\text { Clinical Nutrition }\end{array}$ & Paper & $\begin{array}{l}\text { Household food security status measured by the } \\
\text { US-household food security/hunger survey module } \\
\text { (US-FSSM) is in line with coping strategy indicators } \\
\text { found in urban and rural Indonesia }\end{array}$ & English & 2007 \\
\hline Asia & Food Security & Paper & $\begin{array}{l}\text { How disaggregated should information be for a } \\
\text { sound food security policy? }\end{array}$ & English & 2013 \\
\hline Europe & Food Policy & Paper & $\begin{array}{l}\text { Disentangling the consensus frame of food security: } \\
\text { The case of the EU common agricultural policy } \\
\text { reform debate }\end{array}$ & English & 2014 \\
\hline Europe & $\begin{array}{l}\text { Renewable and Sustainable } \\
\text { Energy Reviews }\end{array}$ & Review paper & $\begin{array}{l}\text { Biomass energy in Vojvodina: Market conditions, } \\
\text { environment and food security }\end{array}$ & English & 2010 \\
\hline Europe & $\begin{array}{l}\text { Economics-The Open Access } \\
\text { Open-Assessment E-Journal }\end{array}$ & Paper & $\begin{array}{l}\text { Russia's food security and climate change: } \\
\text { Looking into the future }\end{array}$ & English & 2013 \\
\hline Europe & Applied Artificial Intelligence & Paper & $\begin{array}{l}\text { Food security risk level assessment: a fuzzy } \\
\text { logic-based approach }\end{array}$ & English & 2013 \\
\hline Europe & Cybernetics and Systems Analysis & Paper & $\begin{array}{l}\text { Integrated modeling of food security management in } \\
\text { Ukraine. I. Model for management of the economic } \\
\text { availability of food }\end{array}$ & English & 2013 \\
\hline Global & Food Policy & Paper & $\begin{array}{l}\text { Policy coherence and food security: The effects of } \\
\text { OECD countries' agricultural policies }\end{array}$ & English & 2014 \\
\hline
\end{tabular}


Table A1. Cont.

\begin{tabular}{|c|c|c|c|c|c|}
\hline Geographical Area & Journal Name & Document Type & Document Title & Language & Year of Publication \\
\hline Global & Pastos y Forrajes & Paper & $\begin{array}{c}\text { Producción de agroenergía a partir de biomasa en } \\
\text { sistemas agroforestales integrados: una alternativa } \\
\text { para lograr la seguridad alimentaria y la } \\
\text { protección ambiental }\end{array}$ & Spanish & 2010 \\
\hline Global & $\begin{array}{l}\text { Revista de Salud Pública } \\
\quad \text { (Bogota, Colombia) }\end{array}$ & Paper & $\begin{array}{l}\text { Biocombustibles, seguridad alimentaria y } \\
\text { cultivos transgenicos. }\end{array}$ & Spanish & 2009 \\
\hline Global & California Agriculture & Paper & $\begin{array}{l}\text { Biofuel policy must evaluate environmental, food } \\
\text { security and energy goals to maximize net benefits }\end{array}$ & English & 2009 \\
\hline Global & $\begin{array}{l}\text { Renewable and Sustainable } \\
\text { Energy Reviews }\end{array}$ & Review paper & Biofuels: Environment, technology and food security & English & 2009 \\
\hline Global & $\begin{array}{l}\text { Chemical Engineering Research } \\
\text { and Design }\end{array}$ & Paper & $\begin{array}{c}\text { Relation of biofuel to bioelectricity and agriculture: } \\
\text { Food security, fuel security, and reducing } \\
\text { greenhouse emissions }\end{array}$ & English & 2009 \\
\hline Global & $\begin{array}{c}\text { Biofuels Biofuels Bioproducts and } \\
\text { Biorefining-Biofpr }\end{array}$ & Paper & $\begin{array}{l}\text { Is the expansion of biofuels at odds with the food } \\
\text { security of developing countries? }\end{array}$ & English & 2007 \\
\hline Global & Environment & Paper & $\begin{array}{c}\text { The ripple effect: Biofuels, food security and } \\
\text { the environment }\end{array}$ & English & 2007 \\
\hline Global & Berichte Uber Landwirtschaft & Paper & $\begin{array}{l}\text { Challenges of global change for agricultural } \\
\text { development and world food security }\end{array}$ & German & 2013 \\
\hline Global & Current History & Paper & Climate change and food security & English & 2013 \\
\hline Global & Science & Review paper & Climate change impacts on global food security & English & 2013 \\
\hline Global & Journal of Crop Improvement & Paper & $\begin{array}{l}\text { Declining agricultural productivity and global } \\
\text { food security }\end{array}$ & English & 2013 \\
\hline Global & Ecohydrology and Hydrobiology & Paper & Food security in a changing climate & English & 2013 \\
\hline Global & Global Change Biology & Review paper & $\begin{array}{c}\text { How much land-based greenhouse gas mitigation can } \\
\text { be achieved without compromising food security and } \\
\text { environmental goals? }\end{array}$ & English & 2013 \\
\hline
\end{tabular}


Table A1. Cont.

\begin{tabular}{|c|c|c|c|c|c|}
\hline Geographical Area & Journal Name & Document Type & Document Title & Language & Year of Publication \\
\hline Global & $\begin{array}{l}\text { Journal of Renewable and } \\
\text { Sustainable Energy }\end{array}$ & Paper & $\begin{array}{l}\text { Achieving food security while switching to low } \\
\text { carbon agriculture }\end{array}$ & English & 2012 \\
\hline Global & $\begin{array}{l}\text { Bulgarian Journal of Agricultural } \\
\text { Science }\end{array}$ & Paper & $\begin{array}{l}\text { Agricultural research in 21st century: Challenges } \\
\text { facing the food security under the impacts of } \\
\text { climate change }\end{array}$ & English & 2012 \\
\hline Global & Environmental Health Perspectives & Review paper & $\begin{array}{c}\text { Climate change and food security: Health impacts in } \\
\text { developed countries }\end{array}$ & English & 2012 \\
\hline Global & $\begin{array}{l}\text { Current Opinion in } \\
\text { Environmental Sustainability }\end{array}$ & Paper & $\begin{array}{l}\text { Climate change, agriculture and food security: } \\
\text { A global partnership to link research and action for } \\
\text { low-income agricultural producers and consumers }\end{array}$ & English & 2012 \\
\hline Global & Irrigation and Drainage & Paper & $\begin{array}{l}\text { Deltas: The new challenges to food security under } \\
\text { climate change }\end{array}$ & English & 2012 \\
\hline Global & $\begin{array}{l}\text { Global Environmental } \\
\text { Change-Human and } \\
\text { Policy Dimensions }\end{array}$ & Paper & $\begin{array}{l}\text { Farmers and perverse outcomes: The quest for food } \\
\text { and energy security, emissions reduction and } \\
\text { climate adaptation }\end{array}$ & English & 2012 \\
\hline Global & $\begin{array}{l}\text { Proceedings of the Royal Society } \\
\text { B-Biological Sciences }\end{array}$ & Review paper & $\begin{array}{l}\text { Food security and climate change: On the potential to } \\
\text { adapt global crop production by active selection to } \\
\text { rising atmospheric carbon dioxide }\end{array}$ & English & 2012 \\
\hline Global & $\begin{array}{l}\text { Isle-Interdisciplinary Studies in } \\
\text { Literature and Environment }\end{array}$ & Paper & $\begin{array}{l}\text { Framing Emerson's "farming": Climate change, peak } \\
\text { oil, and the rhetoric of food security in the } \\
\text { twenty-first century }\end{array}$ & English & 2012 \\
\hline Global & Environmental Science and Policy & Review paper & $\begin{array}{l}\text { Options for support to agriculture and food security } \\
\text { under climate change }\end{array}$ & English & 2012 \\
\hline Global & Euphytica & Review paper & $\begin{array}{l}\text { Implications of climate change for diseases, } \\
\text { crop yields and food security }\end{array}$ & English & 2011 \\
\hline Global & $\begin{array}{l}\text { Journal Fur Verbraucherschutz } \\
\text { Und Lebensmittelsicherheit } \\
\text { (Journal of Consumer Protection } \\
\text { and Food Safety) }\end{array}$ & Paper & $\begin{array}{l}\text { Threat of the "food security" by the effects of } \\
\text { climate change }\end{array}$ & German & 2011 \\
\hline
\end{tabular}


Table A1. Cont.

\begin{tabular}{|c|c|c|c|c|c|}
\hline Geographical Area & Journal Name & Document Type & Document Title & Language & Year of Publication \\
\hline Global & $\begin{array}{l}\text { Wiley Interdisciplinary } \\
\text { Reviews-Climate Change }\end{array}$ & Review paper & Adapting to climate change to sustain food security & English & 2010 \\
\hline Global & Food Security & Paper & $\begin{array}{c}\text { Beyond Copenhagen: Mitigating climate change and } \\
\text { achieving food security through soil } \\
\text { carbon sequestration }\end{array}$ & English & 2010 \\
\hline Global & Food Policy & Paper & $\begin{array}{l}\text { Global water crisis and future food security in an era } \\
\text { of climate change }\end{array}$ & English & 2010 \\
\hline Global & $\begin{array}{c}\text { Progress in Natural } \\
\text { Science-Materials International }\end{array}$ & Review paper & $\begin{array}{l}\text { Climate change impacts on crop yield, crop water } \\
\text { productivity and food security-a review }\end{array}$ & English & 2009 \\
\hline Global & Food Security & Paper & $\begin{array}{l}\text { Declining global per capita agricultural production } \\
\text { and warming oceans threaten food security }\end{array}$ & English & 2009 \\
\hline Global & Science & Paper & $\begin{array}{l}\text { Prioritizing climate change adaptation needs for food } \\
\text { security in } 2030\end{array}$ & English & 2008 \\
\hline Global & $\begin{array}{l}\text { Proceedings of the National } \\
\text { Academy of Sciences of the United } \\
\text { States of America }\end{array}$ & Paper & Global food security under climate change & English & 2007 \\
\hline Global & $\begin{array}{l}\text { Climate Change and Global } \\
\text { Food Security }\end{array}$ & Paper & $\begin{array}{l}\text { Assessing the consequences of climate change for } \\
\text { food security: A view from the intergovernmental } \\
\text { panel on climate change }\end{array}$ & English & 2005 \\
\hline Global & $\begin{array}{l}\text { Philosophical Transactions of the } \\
\text { Royal Society B-Biological Sciences }\end{array}$ & Paper & Climate change and food security & English & 2005 \\
\hline Global & $\begin{array}{l}\text { Climate Change and Global } \\
\text { Food Security }\end{array}$ & Paper & $\begin{array}{l}\text { Climate change and tropical agriculture: Implications } \\
\text { for social vulnerability and food security }\end{array}$ & English & 2005 \\
\hline Global & $\begin{array}{l}\text { Climate Change and Global } \\
\text { Food Security }\end{array}$ & Paper & $\begin{array}{l}\text { Greenhouse gases and food security in } \\
\text { low-income countries }\end{array}$ & English & 2005 \\
\hline Global & $\begin{array}{l}\text { Ids Bulletin-Institute of } \\
\text { Development Studies }\end{array}$ & Paper & Climate change and food security & English & 2004 \\
\hline Global & $\begin{array}{l}\text { Proceedings of the National } \\
\text { Academy of Sciences of the United } \\
\text { States of America }\end{array}$ & Paper & $\begin{array}{l}\text { A systems science perspective and transdisciplinary } \\
\text { models for food and nutrition security }\end{array}$ & English & 2012 \\
\hline
\end{tabular}


Table A1. Cont.

\begin{tabular}{|c|c|c|c|c|c|}
\hline Geographical Area & Journal Name & Document Type & Document Title & Language & Year of Publication \\
\hline Global & $\begin{array}{l}\text { Grey Systems: } \\
\text { Theory and Application }\end{array}$ & Paper & $\begin{array}{l}\text { Grey prediction model-based food security early } \\
\text { warning prediction }\end{array}$ & English & 2012 \\
\hline Global & Food Security & Paper & $\begin{array}{l}\text { A food systems approach to researching food security } \\
\text { and its interactions with global environmental change }\end{array}$ & English & 2011 \\
\hline Global & Ciencia and Saude Coletiva & Paper & $\begin{array}{l}\text { Conceptualizing and measuring food and } \\
\text { nutrition security }\end{array}$ & Portuguese & 2011 \\
\hline Global & Nutrition & Review paper & $\begin{array}{l}\text { Food security measurement in cultural pluralism: } \\
\text { Missing the point or conceptual misunderstanding? }\end{array}$ & English & 2010 \\
\hline Global & Food Security & Paper & Food security: Definition and measurement & English & 2009 \\
\hline Global & Journal of Physical Therapy Science & Review paper & $\begin{array}{l}\text { Measuring household food security: } \\
\text { The global experience }\end{array}$ & English & 2008 \\
\hline Global & $\begin{array}{l}\text { Journal of Tsinghua University } \\
\text { (Science and Technology) }\end{array}$ & Paper & $\begin{array}{l}\text { Optical immuno-sensors chip for environmental } \\
\text { monitoring and food security detection }\end{array}$ & Chinese & 2007 \\
\hline Global & Applied Geography & Paper & $\begin{array}{l}\text { A city and national metric measuring isolation from } \\
\text { the global market for food security assessment }\end{array}$ & English & 2013 \\
\hline Global & $\begin{array}{l}\text { Chinese Journal of } \\
\text { Chromatography }\end{array}$ & Paper & $\begin{array}{l}\text { Development of sample pretreatment } \\
\text { techniques-rapid detection coupling methods for food } \\
\text { security analysis }\end{array}$ & Chinese & 2013 \\
\hline Global & Food Security & Paper & $\begin{array}{l}\text { Rethinking the measurement of food security: } \\
\text { From first principles to best practice }\end{array}$ & English & 2013 \\
\hline Global & Advances in Nutrition & Review paper & $\begin{array}{c}\text { What are we assessing when we measure food } \\
\text { security? A compendium and review of } \\
\text { current metrics }\end{array}$ & English & 2013 \\
\hline Global & Environmental Science and Policy & Paper & $\begin{array}{l}\text { A framework to assess national level vulnerability } \\
\text { from the perspective of food security: The case of } \\
\text { coral reef fisheries }\end{array}$ & English & 2012 \\
\hline $\begin{array}{l}\text { Latin America and } \\
\text { the Caribbean }\end{array}$ & $\begin{array}{l}\text { Energy for Sustainable } \\
\text { Development }\end{array}$ & Paper & $\begin{array}{c}\text { Bioenergy and sustainable development: } \\
\text { The dilemma of food security and climate change in } \\
\text { the Brazilian savannah }\end{array}$ & English & 2010 \\
\hline
\end{tabular}


Table A1. Cont.

\begin{tabular}{|c|c|c|c|c|c|}
\hline Geographical Area & Journal Name & Document Type & Document Title & Language & Year of Publication \\
\hline $\begin{array}{l}\text { Latin America and } \\
\text { the Caribbean }\end{array}$ & $\begin{array}{l}\text { China Agricultural } \\
\text { Economic Review }\end{array}$ & Paper & Biofuels, food security and compensatory subsidies & English & 2010 \\
\hline $\begin{array}{l}\text { Latin America and } \\
\text { the Caribbean }\end{array}$ & $\begin{array}{l}\text { Mitigation and Adaptation } \\
\text { Strategies for Global Change }\end{array}$ & Paper & $\begin{array}{l}\text { Implications of a changing climate on food security } \\
\text { and smallholders' livelihoods in Bogota, Colombia }\end{array}$ & English & 2014 \\
\hline $\begin{array}{l}\text { Latin America and } \\
\text { the Caribbean }\end{array}$ & Climatic Change & Paper & $\begin{array}{c}\text { Climate change and critical thresholds in China's } \\
\text { food security }\end{array}$ & English & 2007 \\
\hline $\begin{array}{l}\text { Latin America and } \\
\text { the Caribbean }\end{array}$ & Ciencia and Saude Coletiva & Paper & $\begin{array}{l}\text { Metodos de analise em programas de seguranca } \\
\text { alimentar e nutricional: Uma experiencia no Brasil. }\end{array}$ & Portuguese & 2013 \\
\hline $\begin{array}{l}\text { Latin America and } \\
\text { the Caribbean }\end{array}$ & Revista Chilena de Nutrición & Paper & $\begin{array}{c}\text { Escalas para medir la seguridad alimentaria en } \\
\text { Colombia: ¿Son válidas? }\end{array}$ & Spanish & 2012 \\
\hline $\begin{array}{l}\text { Latin America and } \\
\text { the Caribbean }\end{array}$ & Revista Chilena de Nutrición & Paper & Seguridad alimentaria en Colombia y modelo rasch & Spanish & 2012 \\
\hline $\begin{array}{l}\text { Latin America and } \\
\text { the Caribbean }\end{array}$ & $\begin{array}{l}\text { Revista de Salud Pública } \\
\text { (Bogota, Colombia) }\end{array}$ & Paper & $\begin{array}{l}\text { Seguridad alimentaria: Un método alterno frente a } \\
\text { uno clásico }\end{array}$ & Spanish & 2010 \\
\hline $\begin{array}{l}\text { Latin America and } \\
\text { the Caribbean }\end{array}$ & Revista Chilena de Nutrición & Paper & $\begin{array}{l}\text { Validéz factorial, consistencia interna y } \\
\text { reproductibilidad de la escala de seguridad } \\
\text { alimentaria en hogares de Bucaramanga, Colombia }\end{array}$ & Spanish & 2009 \\
\hline $\begin{array}{l}\text { Latin America and } \\
\text { the Caribbean }\end{array}$ & Bmc Public Health & Paper & $\begin{array}{c}\text { Internal validity of a household food security scale is } \\
\text { consistent among diverse populations participating in } \\
\text { a food supplement program in Colombia }\end{array}$ & English & 2008 \\
\hline $\begin{array}{l}\text { Latin America and } \\
\text { the Caribbean }\end{array}$ & $\begin{array}{l}\text { European Journal of } \\
\text { Clinical Nutrition }\end{array}$ & Paper & $\begin{array}{l}\text { Psychometric properties of a modified US-household } \\
\text { food security survey module in Campinas, Brazil }\end{array}$ & English & 2008 \\
\hline $\begin{array}{l}\text { Latin America and } \\
\text { the Caribbean }\end{array}$ & Revista de Nutrição & Paper & $\begin{array}{l}\text { Segurança alimentar e nutricional: Desenvolvimento } \\
\text { de indicadores e experimentação em um município da } \\
\text { Bahia, Brasil }\end{array}$ & Portuguese & 2008 \\
\hline $\begin{array}{l}\text { Latin America and } \\
\text { the Caribbean }\end{array}$ & Bmc Public Health & Paper & $\begin{array}{c}\text { The } 18 \text { household Food Security Survey items provide } \\
\text { valid food security classifications for adults and } \\
\text { children in the Caribbean }\end{array}$ & English & 2006 \\
\hline
\end{tabular}


Table A1. Cont.

\begin{tabular}{|c|c|c|c|c|c|}
\hline Geographical Area & Journal Name & Document Type & Document Title & Language & Year of Publication \\
\hline $\begin{array}{l}\text { Latin America and } \\
\text { the Caribbean }\end{array}$ & Public Health Nutrition & Paper & $\begin{array}{l}\text { Self-administration of a food security scale by } \\
\text { adolescents: Item functioning, socio-economic } \\
\text { position and food intakes }\end{array}$ & English & 2005 \\
\hline $\begin{array}{l}\text { Latin America and } \\
\text { the Caribbean }\end{array}$ & Cadernos de Saude Publica & Paper & $\begin{array}{l}\text { Validación de escalas de seguridad alimentaria y de } \\
\text { apoyo social en una población afro-colombiana: } \\
\text { Aplicación en el estudio de prevalencia del estado } \\
\text { nutricional en niños de } 6 \text { a } 18 \text { meses. }\end{array}$ & Spanish & 2005 \\
\hline $\begin{array}{l}\text { Latin America and } \\
\text { the Caribbean }\end{array}$ & $\begin{array}{c}\text { Archivos Latinoamericanos } \\
\text { de Nutrición }\end{array}$ & Paper & $\begin{array}{l}\text { Valoración de informadores clave sobre el plan de } \\
\text { acción de las políticas de seguridad alimentaria } \\
\text { en Colombia. }\end{array}$ & Spanish & 2005 \\
\hline Oceania & Food Policy & Paper & $\begin{array}{l}\text { Impact of water scarcity in Australia on global food } \\
\text { security in an era of climate change }\end{array}$ & English & 2013 \\
\hline Oceania & Regional Environmental Change & Paper & $\begin{array}{l}\text { Dangerous climate change in the Pacific Islands: Food } \\
\text { production and food security }\end{array}$ & English & 2011 \\
\hline
\end{tabular}




\section{References}

1. Asprilla-Perea, J.; Díaz-Puente, J.M. Importance of wild foods to household food security in tropical forest areas. Food Secur. 2019, 11, 15-22. [CrossRef]

2. Asprilla-Perea, J.; Mosquera, Y.; Moreno, A. Proechimys semispinosus (Ratón de Espinas): Una especie de fauna silvestre con Potencial Promisorio para comunidades negras del departamento del Chocó, Pacífico Colombiano. Caldasia 2012, 34, 385-396.

3. Martínez-Pérez, A.; López, P.A.; Gil-Muñoz, A.; Cuevas-Sánchez, J.A. Plantas silvestres útiles y prioritarias identificadas en la Mixteca Poblana, México. Acta Bot. Mex. 2012, 98, 73-98. [CrossRef]

4. Chandra, K.; Nautiyal, B.P.; Nautiyal, M.C. Ethno-botanical resources as supplementary foods and less known wild edible fruits in district Rudraprayag, Uttarakhand, India. J. Hum. Ecol. 2013, 42, 259-271. [CrossRef]

5. Kamga, R.T.; Kouamé, C.; Atangana, A.R.; Chagomoka, T.; Ndango, R. Nutritional evaluation of five African indigenous vegetables. J. Hortic. Res. 2013, 21, 99-106. [CrossRef]

6. Cruz, M.P.; Medeiros, P.M.; Sarmiento-Combariza, I.; Peroni, N.; Albuquerque, U.P. "I eat the manofê so it is not forgotten": Local perceptions and consumption of native wild edible plants from seasonal dry forests in Brazil. J. Ethnobiol. Ethnomed. 2014, 10, 45. [CrossRef]

7. Bortolotto, I.M.; de Mello Amorozo, M.C.; Neto, G.G.; Oldeland, J.; Damasceno-Junior, G.A. Knowledge and use of wild edible plants in rural communities along Paraguay River, Pantanal, Brazil. J. Ethnobiol. Ethnomed. 2015, 11, 46. [CrossRef]

8. $\quad$ Fa, J.E.; Olivero, J.; Real, R.; Farfán, M.A.; Márquez, A.L.; Vargas, J.M.; Ziegler, S.; Wegmann, M.; Brown, D.; Margetts, B.; et al. Disentangling the relative effects of bushmeat availability on human nutrition in central Africa. Sci. Rep. 2015, 5, 8168. [CrossRef]

9. Asprilla-Perea, J.; Díaz-Puente, J.M. Uso de alimentos silvestres de origen animal en comunidades rurales asociadas con bosque húmedo tropical al noroeste de Colombia. Interciencia 2020, 45, 76-83.

10. Monsalve, S.; Mattar, S.; Gonzalez, M. Zoonosis transmitidas por animales silvestres y su impacto en las enfermedades emergentes y reemergentes. Rev. MVZ Córdoba 2009, 14, 1762-1773. [CrossRef]

11. Bonilla-Aldana, D.; Villamil-Gómez, W.E.; Rabaan, A.A.; Rodríguez-Morales, A.J. Una nueva zoonosis viral de preocupación global: COVID-19, enfermedad por coronavirus 2019. Iatreia 2020, 33, 107-110.

12. Palacios, C.; Santos, E.; Cervantes, M.V.; Juárez, M.L. COVID-19, una emergencia de salud pública mundial. Rev. Clín. Esp. 2020. [CrossRef]

13. Rothan, H.A.; Byrareddy, S.N. The epidemiology and pathogenesis of coronavirus disease (COVID-19) outbreak. J. Autoimmun. 2020, 109, 102433. [CrossRef]

14. Programa CE-FAO. Una Introducción a los Conceptos Básicos de la Seguridad Alimentaria; FAO: Roma, Italy, 2011.

15. Groom, B.; Palmer, C. REDD+ and rural livelihoods. Biol. Conserv. 2012, 154, 42-52. [CrossRef]

16. Kashwan, P.; Holahan, R. Nested governance for effective REDD+: Institutional and political arguments. Int. J. Commons 2014, 8, 554-575. [CrossRef]

17. Food and Agriculture Organization of the United Nations; International Fund for Agricultural Development; World Food Programme. El Estado de la Inseguridad Alimentaria en el Mundo. Cumplimiento de los Objetivos Internacionales para 2015 en Relación con el Hambre: Balance de los Desiguales Progresos; CreateSpace Independent Publishing Platform: Roma, Italy, 2015.

18. Robinson, J.G.; Bennett, E.L. Hunting for Sustainability in Tropical Forests; Robinson, J., Bennett, E., Eds.; Columbia University Press: Columbia, NY, USA, 2000.

19. Van den Eynden, V.; Cueva, E.; Cabrera, O. Wild foods from Southern Ecuador. Econ. Bot. 2003, 57, 576-603. [CrossRef]

20. Schulp, C.J.E.; Thuiller, W.; Verburg, P.H. Wild food in Europe: A synthesis of knowledge and data of terrestrial wild food as an ecosystem service. Ecol. Econ. 2014, 105, 292-305. [CrossRef]

21. Termote, C.; Raneri, J.; Deptford, A.; Cogill, B. Assessing the potential of wild foods to reduce the cost of a nutritionally adequate diet: An example from eastern Baringo District, Kenya. Food Nutr. Bull. 2014, 35, 458-479. [CrossRef]

22. Erskine, W.; Ximenes, A.; Glazebrook, D.; da Costa, M.; Lopes, M.; Spyckerelle, L.; Williams, R. The role of wild foods in food security: The example of Timor-Leste. Food Secur. 2015, 7, 55-65. [CrossRef] 
23. Leterme, P.; Buldgen, A.; Estrada, F.; Londoño, A.M. Mineral content of tropical fruits and unconventional foods of the Andes and the rain forest of Colombia. Food Chem. 2006, 95, 644-652. [CrossRef]

24. Tejada, R.; Chao, L.; Gómez, H.; Painter, R.E.L.; Wallace, R.B. Evaluación sobre el uso de la fauna silvestre en la Tierra Comunitaria de Origen Tacana, Bolivia. Ecol. Boliv. 2006, 41, 138-148.

25. Bustacara, A.; Joya, F.D. Elaboración de Tres Productos Cárnicos: Chorizo, Longaniza y Hamburguesa, con 100\% Carne de Babilla; Facultad de Zootecnia, Universidad de la Salle: Bogotá, Colombia, 2007.

26. Palomino, C.; Molina, Y.; Pérez, E. Atributos físicos y composición química de harinas y almidones de los tubérculos de Colocasia esculenta (L.) Schott y Xanthosoma sagittifolium (L.) Schott. Rev. Fac. Agron. 2010, 36, 58-66.

27. Ramírez-Rivera, J.; Juárez-Barrientos, J.M.; Herrera-Torres, E.; Navarro-Cortez, R.O.; Hernández-Santos, B. Caracterización fisicoquímica, funcional y contenido fenólico de harina de malanga (Colocasia esculenta) cultivada en la región de Tuxtepec, Oaxaca, México. Cienc. Mar 2011, 15, 37-47.

28. Torres-Rapelo, A.L.; Montero-Castillo, P.M.; Julio-González, L.C. Utilización de almidón de Malanga (Colocasia esculenta L.) en la elaboración de salchichas tipo Frankfurt. Biotecnol. Sect. Agropecu. Agroind. 2014, 12, 97-105.

29. Uchôa-Thomaz, A.M.A.; Sousa, A.E.; Carioca, J.O.; de Morais, S.M.; de Lima, A.; Martins, C.; Alexandrino, C.; Ferreira, P.A. Chemical composition, fatty acid profile and bioactive compounds of guava seeds (Psidium guajava L.). Food Sci. Technol. 2014, 34, 485-492. [CrossRef]

30. Serpa, A.M.; Vásquez, D.C.; Castrillón, D.C.; Hincapié, G.A. Comparison of two dehydration techniques for "pear" guava (Psidium guajava L.) on the effects of the vitamin C content and on the behavior of the technical and functional properties of the dietary fiber. Rev. Lasallista Investig. 2015, 12, 10-20.

31. Alvis, A.; Romero, P.; Granados, C.; Torrenegra, M.; Pajaro-Castro, N. Evaluación del color, las propiedades texturales y sensoriales de salchicha elaborada con carne de babilla (Caiman Crocodilus Fuscus). Rev. Chil. Nutr. 2017, 44, 89-94. [CrossRef]

32. Sardeshpande, M.; Shackleton, C. Wild Edible Fruits: A Systematic Review of an Under-Researched Multifunctional NTFP (Non-Timber Forest Product). Forests 2019, 10, 467. [CrossRef]

33. Rana, Z.H.; Alam, M.K.; Akhtaruzzaman, M. Nutritional Composition, Total Phenolic Content, Antioxidant and $\alpha$-Amylase Inhibitory Activities of Different Fractions of Selected Wild Edible Plants. Antioxidants 2019, 8, 203. [CrossRef]

34. Alam, M.K.; Rana, Z.H.; Islam, S.N.; Akhtaruzzaman, M. Total phenolic content and antioxidant activity of methanolic extract of selected wild leafy vegetables grown in Bangladesh: A cheapest source of antioxidants. Potravin. Slovak J. Food Sci. 2019, 13, 287-293. [CrossRef]

35. Alam, M.K.; Rana, Z.H.; Kabir, N.; Begum, P.; Kawsar, M.; Khatun, M.; Ahsan, M.; Islam, S.N. Total Phenolics, Total Carotenoids and Antioxidant Activity of Selected Unconventional Vegetables Growing in Bangladesh. Curr. Nutr. Food Sci. 2019, 15, 1. [CrossRef]

36. Alam, M.K.; Rana, Z.H.; Islam, S.N.; Akhtaruzzaman, M. Comparative assessment of nutritional composition, polyphenol profile, antidiabetic and antioxidative properties of selected edible wild plant species of Bangladesh. Food Chem. 2020, 320, 126646. [CrossRef] [PubMed]

37. Larrazábal, L. Crianza en cautiverio de perezoso de dos dedos (Choloepus didactylus). Edentata 2004, 6, 30-36. [CrossRef]

38. Viloria, H.; Córdova, C. Production system of taro (Colocasia esculenta L. Schott) at Manuel Renaud Parish, Antonio Díaz Municipality, Delta Amacuro State, Venezuela. Rev. Cient. UDO Agríc. 2008, 8, 98-106.

39. Suárez, J.; Camacaro, M.P.; Giménez, A. Efecto de la temperatura y estado de madurez sobre la calidad postcosecha de la fruta de guayaba (Psidium guajava L.) procedente de Mercabar, estado Lara, Venezuela. Rev. Cient. UDO Agríc. 2009, 9, 60-69.

40. Cifuentes, L.; Moreno, F.; Arango, D.A. Fenología reproductiva y productividad de Oenocarpus bataua (Mart.) en bosques inundables del Chocó Biogeográfico, Colombia. Biota Neotrop. 2010, 10, 101-110. [CrossRef]

41. Álvarez, V.M.; Muriel, S.; Osorio, N. Plantas asociadas al turismo y los sistemas tradicionales de manejo en el occidente cercano antioqueño (Colombia). Ambient. Desarro. 2015, 19, 67-82. [CrossRef]

42. Sicchar-Valdez, L.A.; Acosta-Díaz, A.; Panduro, S.; Panduro, M.; Ramírez, S.; Monge, M.; Villacorta, D. Supervivencia a condiciones extremas en cautiverio de Caiman crocodilus (Linnaeus 1578), lagarto blanco, en Iquitos, Perú. Conoc. Amaz. 2015, 2, 81-85. 
43. Sheppard, R.J.; Meitner, M. Using multi-criteria analysis and visualisation for sustainable forest management planning with stakeholder groups. For. Ecol. Manag. 2005, 207, 171-187. [CrossRef]

44. Díaz-Balteiro, L.; Romero, C. Sustainability of forest management plans: A discrete goal programming approach. J. Environ. Manag. 2004, 71, 351-359. [CrossRef]

45. Mendoza, G.A.; Prabhu, R. Qualitative multi-criteria approaches to assessing indicators of sustainable forest resource management. For. Ecol. Manag. 2003, 174, 107-126. [CrossRef]

46. Mendoza, G.A.; Prabhu, R. Combining participatory modeling and multicriteria analysis for community-based management. For. Ecol. Manag. 2005, 207, 145-156. [CrossRef]

47. Sugimura, K.; Howard, T.E. Incorporating social factors to improve the Japanese forest zoning process. For. Policy Econ. 2008, 10, 161-173. [CrossRef]

48. Thomson, A.J. How should we manage knowledge ecosystems? Using additive knowledge management. In Sustainable Forestry from Monitoring and Modelling to Knowledge Management \& Policy Science; Reynolds, K.M., Thomson, A.J., Köhl, M., Shannon, M.A., Ray, D., Rennolls, K., Eds.; CAB International: Wallingford, UK, 2007; pp. 461-480. ISBN 10-1845931742.

49. Mustajoki, J.; Saarikoski, H.; Marttunen, M.; Ahtikoski, A.; Hallikainen, V.; Helle, T.; Ylisirniö, A.L. Use of decision analysis interviews to support the sustainable use of the forests in Finnish Upper Lapland. J. Environ. Manag. 2011, 92, 1550-1563. [CrossRef] [PubMed]

50. Ocampo-Melgar, A.; Bautista, S.; de Steiguer, J.E.; Orr, B.J. Potential of an outranking multi-criteria approach to support the participatory assessment of land management actions. J. Environ. Manag. 2017, 195, 70-77. [CrossRef]

51. Esmail, B.A.; Geneletti, D. Multi-criteria decision analysis for nature conservation: A review of 20 years of applications. Methods Ecol. Evol. 2017, 42-53. [CrossRef]

52. Díaz-Balteiro, L.; Romero, C. Making forestry decisions with multiple criteria: A review and an assessment. For. Ecol. Manag. 2008, 255, 3222-3241. [CrossRef]

53. Labin, S.N. Research synthesis: Toward broad-based evidence. In Fundamental Issues in Evaluation; Smith, N., Brandon, P.R., Eds.; Guilford Press: New York, NY, USA, 2007; pp. 89-110.

54. Mavengahama, S.; McLachlan, M.; de Clercq, W. The role of wild vegetable species in household food security in maize based subsistence cropping systems. Food Secur. 2013, 5, 227-233. [CrossRef]

55. Saaty, T.L. Axiomatic Foundation of the Analytic Hierarchy Process. Manag. Sci. 1986, 32, 841-855. [CrossRef]

56. Saaty, T.L. A scaling method for priorities in hierarchical structures. J. Math. Psychol. 1977, 15, $234-281$. [CrossRef]

57. Saaty, T.L. The Analytic Hierarchy Process; McGraw Hill: New York, NY, USA, 1980; p. 286.

58. Peres, C.A. Synergistic effects of subsistence hunting and habitat fragmentation on Amazonian forest vertebrates. Conserv. Biol. 2001, 15, 1490-1505. [CrossRef]

59. Fa, J.E.; Currie, D.; Meeuwig, J. Bushmeat and food security in the Congo Basin: Linkages between wildlife and people's future. Environ. Conserv. 2003, 30, 71-78. [CrossRef]

60. Laurance, W.F.; Croes, B.M.; Tchignoumba, L.; Lahm, S.A.; Alonso, A.; Lee, M.E.; Campbell, P.; Ondzeano, C. Impacts of roads and hunting on Central African rainforest mammals. Conserv. Biol. 2006, 20, 1251-1261. [CrossRef] [PubMed]

61. Wright, S.J.; Muller-Landau, H.C. The future of tropical forest species. Biotropica 2006, 38, 287-301. [CrossRef]

62. Fa, J.E.; Brown, D. Impacts of hunting on mammals in African tropical moist forests: A review and synthesis. Mamm. Rev. 2009, 39, 231-264. [CrossRef]

63. Pandey, M.; Abidi, A.B.; Singh, S.; Singh, R.P. Nutritional evaluation of leafy vegetable paratha. J. Hum. Ecol. 2006, 19, 155-156. [CrossRef]

64. Keatinge, D. Vegetables: Less Visible, but Vital for Human Health. Why Nutrient-Dense Indigenous Vegetables Must Be on the Plate for Economic Development, Food Security, and Health; The World Vegetables Center (AVRDC), News Brief: Shanhua District, Taiwan, 2012.

65. Leroy, E.M.; Rouquet, P.; Formenty, P.; Souquière, S.; Kilbourne, A.; Froment, J.M.; Bermejo, M.; Smit, S.; Karesh, W.; Swanepoel, R.; et al. Multiple Ebola Virus Transmission Events and Rapid Decline of Central African Wildlife. Science 2004, 303, 387-390. [CrossRef]

66. Bell, D.; Roberton, S.; Hunter, P.R. Animal origins of SARS coronavirus: Possible links with the international trade in small carnivores. Philos. Trans. R. Soc. Lond. B Biol. Sci. 2004, 359, 1107-1114. [CrossRef] 
67. Karesh, W.B.; Cook, R.A.; Bennett, E.L.; Newcomb, J. Wildlife trade and global disease emergence. Emerg. Infect. Dis. 2005, 11, 1000. [CrossRef]

68. Arenas, P.; Scarpa, G. Edible wild plants of the Chorote Indians, Gran Chaco, Argentina. Bot. J. Linn. Soc. 2007, 153, 73-85. [CrossRef]

69. Dejene, T.; Agamy, M.S.; Agúndez, D.; Martin-Pinto, P. Ethnobotanical Survey of Wild Edible Fruit Tree Species in Lowland Areas of Ethiopia. Forests 2020, 11, 177. [CrossRef]

70. Fungo, R.; Muyonga, J.H.; Ngondi, J.L.; Mikolo-Yobo, C.; Iponga, D.M.; Ngoye, A.; Nchuaji, E.; Chupezi, J. Nutrient and Bioactive Composition of Five Gabonese Forest Fruits and Their Potential Contribution to Dietary Reference Intakes of Children Aged 1-3 Years and Women Aged 19-60 Years. Forests 2019, 10, 86. [CrossRef]

71. Harris, F.M.; Mohammed, S. Relying on Nature: Wild Foods in Northern Nigeria. AMBIO 2003, 32, $24-29$. [CrossRef] [PubMed]

(C) 2020 by the authors. Licensee MDPI, Basel, Switzerland. This article is an open access article distributed under the terms and conditions of the Creative Commons Attribution (CC BY) license (http://creativecommons.org/licenses/by/4.0/). 